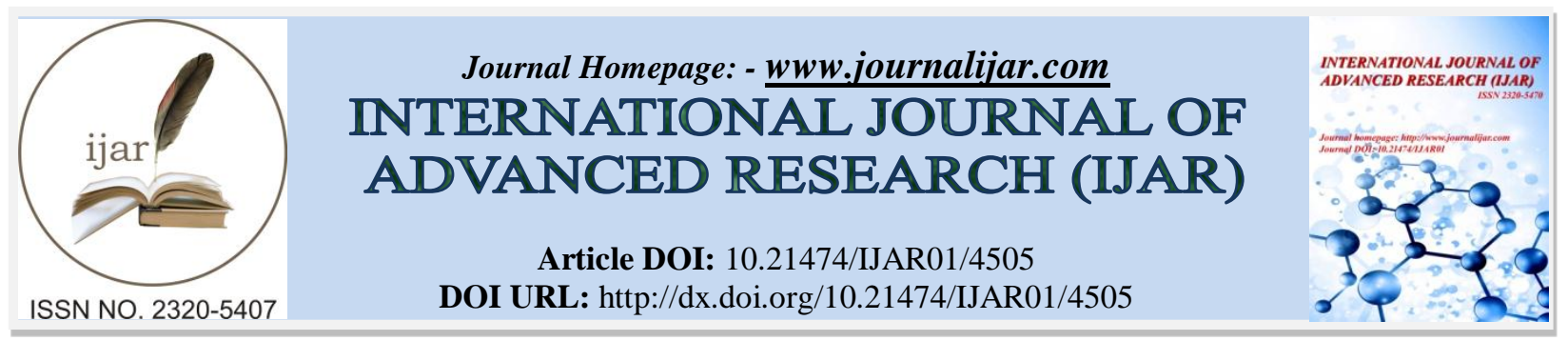

RESEARCH ARTICLE

\title{
CLINICOPATHOLOGICAL SIGNIFICANCES OF STEM CELL MARKERS SOX-2\& PIWIL1 EXPRESSIONS IN ENDOMETROID CARCINOMA OF THE UTERUS.
}

Dina A. Khairy and Abla S. Mahmoud.

Department of Pathology, Faculty of Medicine, Beni-Suef University, Egypt.

\section{Manuscript Info}

\section{Manuscript History}

Received: 17 April 2017

Final Accepted: 19 May 2017

Published: June 2017

Key words:-

SOX-2; Piwil 1; endometroid carcinoma; grade; immunohistochemistry

\section{Abstract}

Background: Endometroid carcinoma (EMC) is the commonest subtype of endometrial cancer. Recent researchers had proved the role of cancer stem cells (CSCs) in its carcinogenesis. There are many stem cell-related transcription factors, such as Sex-determining region y (SRY)-Box2 (SOX2) which is a SOX family member that had many roles in controlling stem cell properties and differentiation. But, the accurate clinicopathological role of SOX-2 in endometroid carcinoma is still not sufficiently clarified. The epithelial-mesenchymal transition (EMT) is the process in which the epithelial cell loses its polarity and cell to cell adhesions, and having motile criteria. Recently, a link was found between EMT and acquiring stem cell-like properties of tumor cells. The Piwill gene is a Piwi gene family member that was found to be required for self-renewal and division of stem cell. Proving Piwill roles in EMT and acquiring stem cell-like properties in EMC need more clarification aiming at understanding endometrial carcinogenesis.

The aim of the work: to evaluate stem cell markers SOX-2 and Piwill co-expression in endometroid carcinoma (EMC) and to assess the correlation between their expressions and clinocopathological features of such type of malignancy.

Patients And Methods: we assesses SOX-2 and Piwill co-expression by using immunohistochemistry in sections from fifty blocks of paraffin of EMC then analyzed correlations between the levels of SOX-2 and Piwill co-expression and the clinicopathological parameters of patients.

Results: High expression of SOX-2 was detected in 28 out of 50 $(56 \%)$ and high expression $\mathrm{f}$ Piwill was detected in 32 out of 50 $(64 \%)$ cases of EMC. High expression of SOX-2 was significantly positively correlated with higher grade $\&$ advanced stage of the tumor, presence of L.N metastases \& distant metastases $(\mathrm{p}<0.001)$, presence of myometrial $(\mathrm{p}=0.002)$, lymphovascular $(\mathrm{p}=0.006) \&$ parametrial $(\mathrm{p}=0.008)$, serosal $(\mathrm{p}=0.04)$, cervical stromal $(\mathrm{p}=0.003) \&$ adnexal invasion $(\mathrm{p}=0.002)$. High expression $\mathrm{f}$ Piwill was significantly positively correlated with the presence of distant metastases $(\mathrm{p}=0.009)$, higher grade $(\mathrm{p}=0.002) \&$ advanced stage of the tumor, 
presence of L.N metastases $(\mathrm{p}<0.001)$, presence of myometrial $(\mathrm{p}=0.008)$, lymphovascular $(\mathrm{p}=0.006)$, parametrial, serosal $(\mathrm{p}=0.005)$, cervical stromal $(\mathrm{p}=0.003)$ and adnexal invasion $(\mathrm{p}=0.002)$. Expression of SOX2 were significantly positively correlated with Piwill ( $\mathrm{p}<0.001)$.

Conclusion: SOX-2\& Piwil 1 co-expression correlates with poor clinicopathological parameters of endometroid carcinoma

Copy Right, IJAR, 2017,. All rights reserved.

\section{Introduction:-}

Endometrial carcinoma (EC) is a malignant tumor that originated from endometrial epithelium; it forms about 20$30 \%$ of female reproductive system malignancies. The incidence and fatality of EC has increased recently, due to increased hypertension, obesity, diabetes incidences and increased life span [1]. EC is the commonest gynecologic cancer in developed countries and the $2^{\text {nd }}$ commonest gynecologic cancer in the developing countries, as cancer cervix remained the first [2]. Endometrioid carcinoma (EMC) is the commonest histopathologic EC subtype and is characterized by the presence of tumor cells that are surrounded by stromal cells and a few subset of of cells having cancer stem cells (CSCs) criteria [3]. Recent researchers had proved the role of cancer stem cells (CSCs) in EMC carcinogenesis [4\& 5]. As oncogenic mutations could be happen over so many years, it is logistic that; as only adult stem/progenitor cells have a long lifespan that could be sufficiently enough for accumulation of genetic changes that will be needed for cancer development. So, CSCs could be responsible for cancer invasion, carcinogenesis and spread [3]. The future anti-cancer therapies must target these CSCs by specific therapeutics that required detailed identification of their specific markers [6].Sex-determining-region-y (SRY)-Box2 (SOX-2) is a SOX family member of transcription factors that had many functions in controlling stem cell properties [7\& 8]. Uptillnow there are conflicting results about the exact role of SOX-2 aberrant expression in EMC. The epithelial-mesenchymal transition (EMT) is the process in which the epithelial cell loses its polarity and cell to cell adhesions, and having motile criteria. Recently, a link was found between EMT and acquiring stem cell-like properties of tumor cells [9]. The Piwill gene is a Piwi gene family member that was found to be required for self-renewal and division of stem cell [10\& 11]. The human PIWI subfamily contains four members; PIWI L1-HIWI, PIWI L2-HILI, PIWI L3, and PIWI L4-HIWI2, which had many roles in the widespread regulation of biological process e.g. cancer epigenetics [12] and the stability of RNA [13]. Previous researchers tried to prove the relations between Piwill and EMT in acquiring stem cell-like properties in cancer development aiming to provide insights into detecting Piwill role in endometrial oncogenesis [14\& 15]. But accurate results have not been sufficiently clarified yet.

The aim of the work; to evaluate stem cell markers SOX-2 and Piwill co-expression in endometroid carcinoma (EMC) and to assess the correlation between their expressions and clinocopathological features of such type of malignancy.

\section{Patients And Methods:-}

We assesses SOX-2 and Piwill co-expression by using immunohistochemistry in sections from fifty paraffin blocks which were diagnosed as EMC in Pathology department, Faculty of medicine, Beni-Suif University\& Zagazig University in the period from january 2012 to january 2017. The study design was accepted by the IRB ethical committee.

We acquired the clinicopathological data as age, cancer size, grade and stage from the archives of pathology departments from both universities. We established EMC stages\& grades according to the surgical staging system [Federation International of Gynecology and Obstetrics (FIGO) (2009)] [16\& 17]. We analyzed correlations between the levels of SOX-2 and Piwill co-expression and all the clinicopathological parameters.

\section{Immunohistochemical staining:-}

Streptavidine-biotin technique was used for immunohistochemical staining with incubation with primary - rabbit mono clonal anti-Sox-2 (D6D9 XP-Cell Signalling Technology (Wirginia, US) \& with primary anti- rabbit polyclonal anti-Piwil1 (1:100, ab105393, Abcam) [18]. 


\section{Evaluation of immunohistochemical expression of SOX2:-}

The intensity of nuclear SOX2 expression was scored as followed (0, absent expression; 1 , weak; 2, moderate and 3, strong expression) and the extent of stained cancer cells was assessed as followed ( 0 , stain expression in < $1 \%$ of cancer cells; $1,1-5 \%$ of cancer cells; $2,6-10 \%$ of cancer cells; $3,11-25 \%$ of cancer cells; $4,26-50 \%$ of cancer cells and $5,>50 \%$ of cancer cells). We multiplied the intensity scores with the extent scores to reach the final immunoreactivity scores ranged from 0-12 [19]. We used the cut off value of 4 above which was considered as overexpression and below which is low expression.

\section{Evaluation of immunohistochemical Piwil1 staining:-}

The extent of stained cancer cells was assessed as followed $(0=$ absent stain, $1=25 \%$ of cancer cells were stained, $2=25-50 \%$ of cancer cells were stained, $3=50-75 \%$ of cancer cells were stained and $4=75 \%$ of cancer cells were stained $)$ and the intensity stain was scored as followed $(0=$ negative stain, $1=$ weak expression of the stain, 2 $=$ moderate expression of the stain, and $3=$ strong expression of the stain). We summated the intensity scores with the extent scores to reach the final immunoreactivity scores ranged from 0-6 [20]. We used the cut off value of 3 above which was considered as overexpression and below which is low expression.

\section{Statistical Analysis:-}

We performed the statistics by using SPSS 22.0 (SPSS Inc., Chicago, IL, USA) and (MedCalc Software 13, Belgium). The percent of categorical variables had been compared using Chi-square or Fisher's exact tests when were appropriate. Independent sample Student's t-test was used to compare between two groups of variables. Kruskal Wallis $\mathrm{H}$ test was used to compare between more than two groups of non-normally distributed variables. A p-value $<0.05$ is considered significant.

\section{Results:-}

Patient Characteristics:-

The clinical characteristics of the 50 patients with EMC that were included in our study are summarized in Table (1) with age ranged from (35-65) years\& the Mean age is: $50.10 \pm 5.82$ years.

\section{Immunohistochemical Results:-}

\section{SOX-2 Results:-}

- High expression of SOX-2 was detected in 28 out of 50 (56\%) cases of EMC and it was significantly positively correlated with advanced age of the patient $(\mathrm{p}=0.04)$, larger tumor size $(\mathrm{p}=0.007)$, higher grade, advanced stage, presence of L.N and distant metastases $(\mathrm{p}<0.001)$, presence of myometrial $(\mathrm{p}=0.002)$, lymphovascular $(\mathrm{p}=0.006) \&$ parametrial $(\mathrm{p}=0.008)$, serosal $(\mathrm{p}=0.04)$, cervical stromal $(\mathrm{p}=0.003)$ and adnexal invasions ( $\mathrm{p}=0.002)$. Table 2, Fig 1

\section{Piwil1Expression:-}

- High expression f Piwill was detected in 32 out of 50 (64\%) cases of EMC and it was significantly positively correlated with advanced age of the patient $(\mathrm{p}=0.02)$, larger tumor size, presence of distant metastases $(\mathrm{p}=0.009)$, higher $\operatorname{grade}(\mathrm{p}=0.002)$, advanced stage, presence of L.N metastases $(\mathrm{p}<0.001)$, presence of myometrial $(\mathrm{p}=0.008)$, lymphovascular $(\mathrm{p}=0.006)$, parametrial, serosal $(\mathrm{p}=0.005)$, cervical stromal $(\mathrm{p}=0.003)$ and adnexal invasions ( $\mathrm{p}=0.002$ ). Table 3, Fig 2

- Expression of SOX-2 was significantly positively correlated with that of Piwill $(\mathrm{p}<0.001)$. 


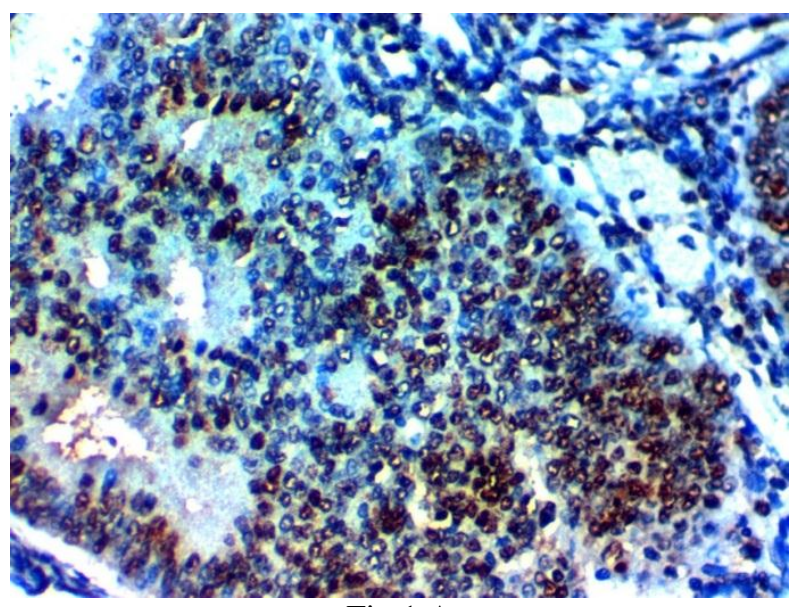

Fig $1 \mathrm{~A}$

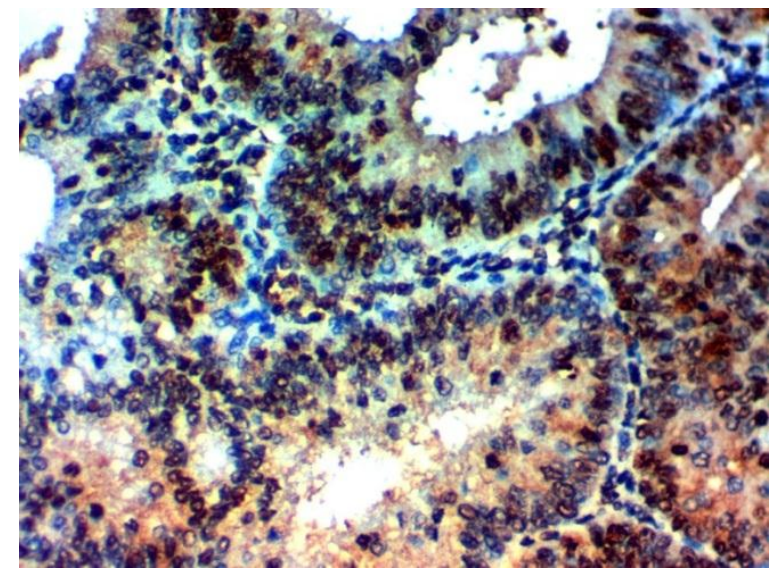

Fig 1B

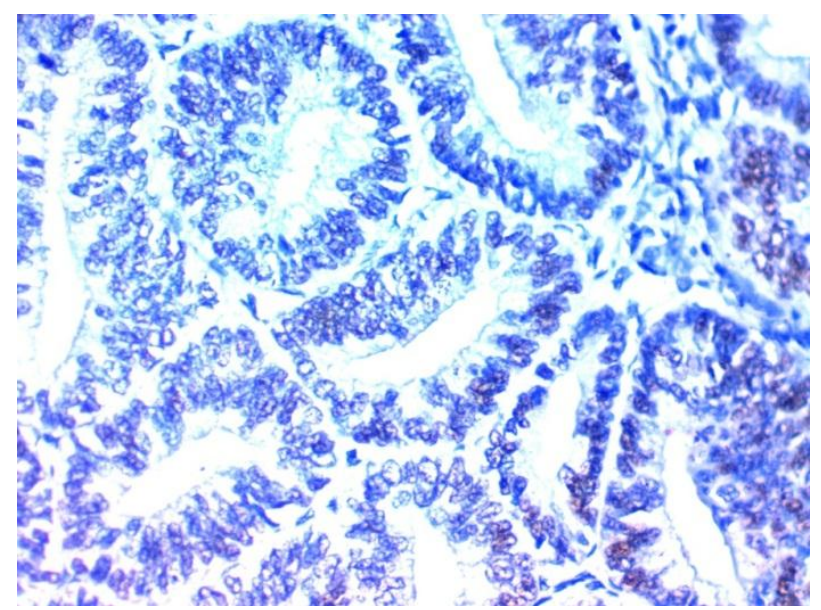

Fig 1C 


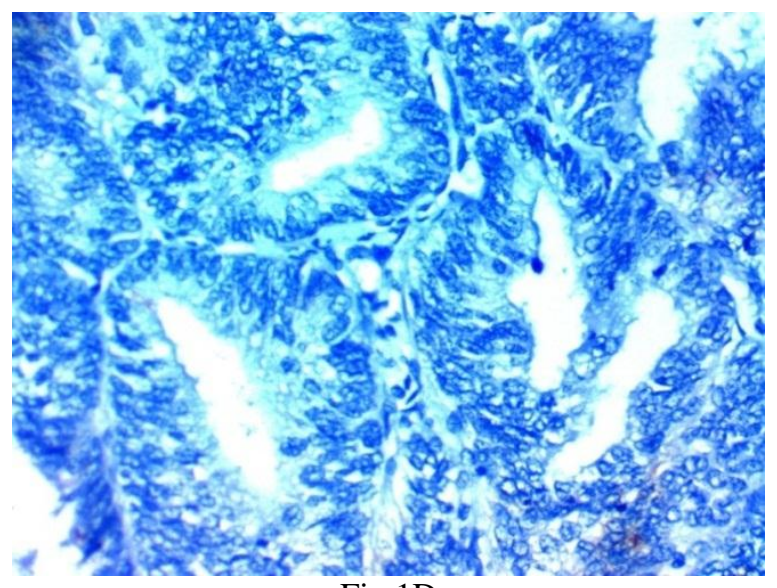

Fig 1D

Figure1. Immunohistochemical staining of SOX-2 in endometroid carcinoma (EMC) :(A) High expression in the nucleus of EMC grade III x400 (B) High expression in the nucleus of EMC grade II x400. (C) Low expression in the nucleus of EMC grade Ix400. (D) Negative expression in the nucleus of EMC grade Ix400.

Note: High SOX-2 immunohistochemical expression in high grade EMC and low expression in low grade EMC: A, B, C\& D the original magnification was $\times 400$

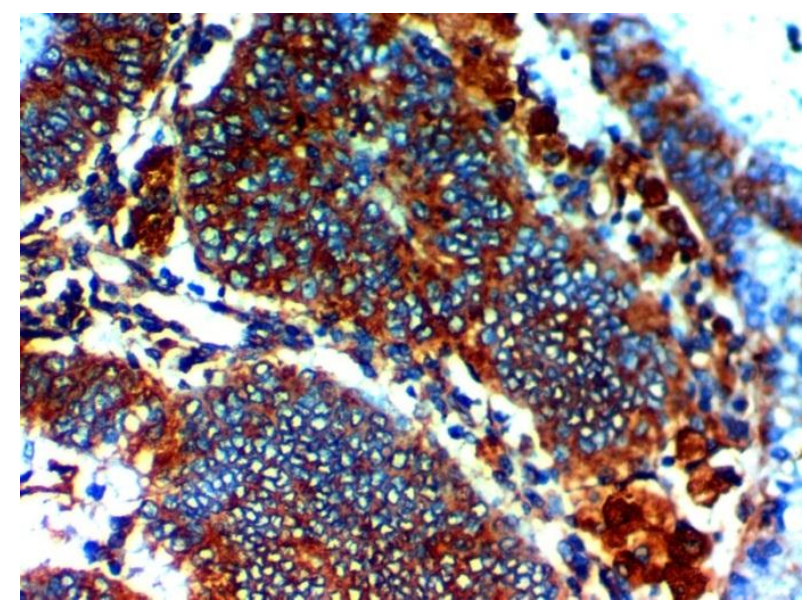

Fig 2 A

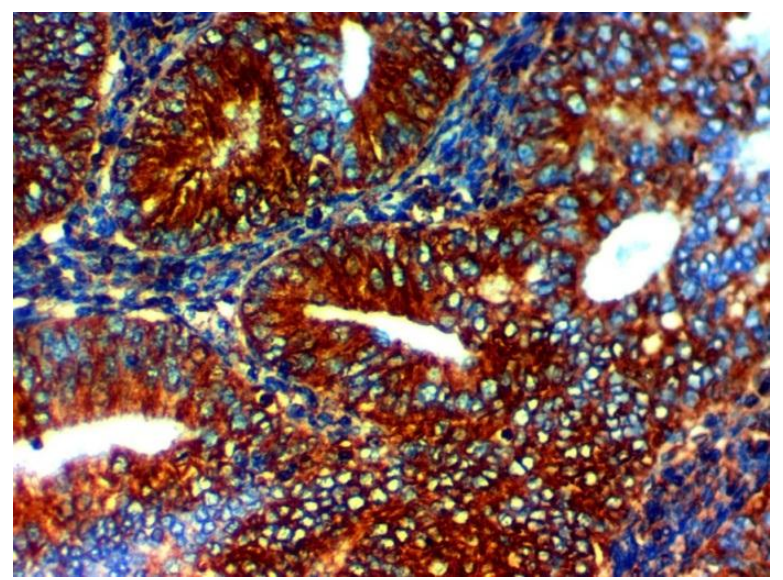

Fig 2 B 


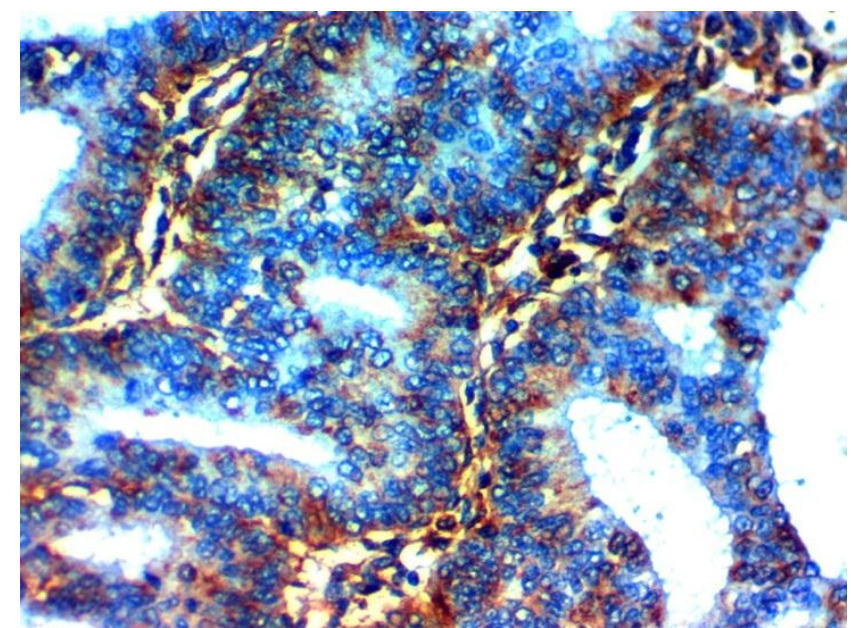

Fig $2 \mathrm{C}$

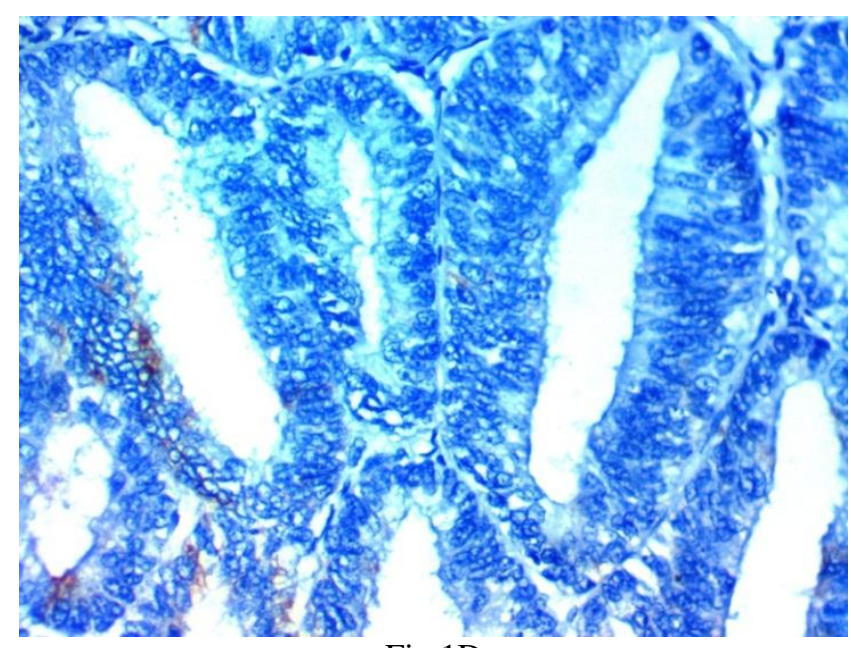

Fig 1D

Figure 2. Immunohistochemical staining of Piwill in endometroid carcinoma (EMC) :(A) High expression in the cytoplasm of EMC grade III x400 (B) High expression in the cytoplasm of EMC grade II x400. (C) Low expression in the cytoplasm of EMC grade Ix400. (D) Negative expression in the cytoplasm of EMC grade Ix400.

Note: High Piwil1 immunohistochemical expression in high grade EMC and low expression in low grade EMC: A, B, C\& D the original magnification was $\times 400$

Table 1:- Demographic data of our patients

\begin{tabular}{|c|c|c|}
\hline Characteristics & No. & Percent \\
\hline Age (years & & \pm 5.82 \\
\hline Mean \pm SD & 50.10 & $(35-65)$ \\
\hline Median (Range & 50 & $60 \%$ \\
\hline$\leq 55$ years & 30 & $40 \%$ \\
\hline$>55$ years & 20 & $100 \%$ \\
\hline Histopathology & & \\
\hline Endometroid & 50 & $30 \%$ \\
\hline Grade & & $50 \%$ \\
\hline Grade I & 15 & \\
\hline Grade II & 25 & \\
\hline
\end{tabular}




\begin{tabular}{|c|c|c|}
\hline Grade III & 10 & $20 \%$ \\
\hline \multicolumn{3}{|l|}{ Size } \\
\hline$<4 \mathrm{~cm}$ & 20 & $40 \%$ \\
\hline$>4 \mathrm{~cm}$ & 30 & $60 \%$ \\
\hline \multicolumn{3}{|l|}{ Myometrial invasion } \\
\hline$<50 \%$ & 18 & $36 \%$ \\
\hline$>50 \%$ & 32 & $64 \%$ \\
\hline \multicolumn{3}{|l|}{ LVSI } \\
\hline Absent & 32 & $64 \%$ \\
\hline Present & 18 & $36 \%$ \\
\hline \multicolumn{3}{|l|}{ Cervical stromal invasion } \\
\hline Absent & 20 & $40 \%$ \\
\hline Present & 30 & $60 \%$ \\
\hline \multicolumn{3}{|l|}{ Parametrial extension } \\
\hline Absent & 40 & $80 \%$ \\
\hline Present & 10 & $20 \%$ \\
\hline \multicolumn{3}{|l|}{ Serosal invasion } \\
\hline Absent & 40 & $80 \%$ \\
\hline Present & 10 & $40 \%$ \\
\hline \multicolumn{3}{|l|}{ Adnexal invasion } \\
\hline Absent & 35 & $70 \%$ \\
\hline Present & 15 & $30 \%$ \\
\hline \multicolumn{3}{|l|}{ Peritoneal cytology } \\
\hline Negative & 25 & $50 \%$ \\
\hline Positive & 25 & $50 \%$ \\
\hline \multicolumn{3}{|l|}{ LN } \\
\hline Node negative & 30 & $60 \%$ \\
\hline \multicolumn{3}{|l|}{$\underline{\mathrm{M}}$} \\
\hline M0 (non-metastatic) & 40 & $80 \%$ \\
\hline M1 (metastatic) & 10 & $20 \%$ \\
\hline \multicolumn{3}{|l|}{ FIGO Stage } \\
\hline Stage I & 15 & $30 \%$ \\
\hline Stage II & 10 & $20 \%$ \\
\hline Stage III & 15 & $30 \%$ \\
\hline Stage IV & 10 & $20 \%$ \\
\hline
\end{tabular}

Categorical variables were expressed as number (percentage), continuous variables were expressed as mean \pm SD \& median (range).

Table 2:- correlation between clinicopathological features and SOX2 expression in our patients

\begin{tabular}{|c|c|c|c|c|c|c|c|}
\hline \multirow[t]{3}{*}{ Characteristics } & \multirow{2}{*}{\multicolumn{2}{|c|}{$(\mathrm{N}=60)$}} & \multicolumn{4}{|c|}{ SOX2 } & \multirow[t]{3}{*}{ p-value } \\
\hline & & & \multicolumn{2}{|c|}{$\begin{array}{c}\text { Low } \\
(\mathrm{N}=22)\end{array}$} & \multicolumn{2}{|c|}{$\begin{array}{c}\text { High } \\
(\mathrm{N}=28)\end{array}$} & \\
\hline & No. & $(\%)$ & No. & $(\%)$ & No. & $(\%)$ & \\
\hline \multicolumn{8}{|l|}{ Age (years) } \\
\hline Mean \pm SD & 50.10 & \pm 5.82 & 48.48 & \pm 5.68 & 48.35 & \pm 8.18 & \multirow[t]{2}{*}{$0.06^{*}$} \\
\hline Median (Range) & 50 & $(35-65)$ & 50 & $(30-60)$ & 50 & $(30-65)$ & \\
\hline$\leq 55$ years & 30 & $(60 \%)$ & 18 & $(60 \%)$ & 12 & $(40 \%)$ & \multirow[t]{2}{*}{$0.04 \dagger$} \\
\hline$>55$ years & 20 & $(40 \%)$ & 4 & $(20 \%)$ & 16 & $(80 \%)$ & \\
\hline \multicolumn{8}{|l|}{ Grade } \\
\hline Grade I & 15 & $(30 \%)$ & 15 & $(100 \%)$ & 0 & $(0 \%)$ & \multirow[t]{3}{*}{$0.001 \S$} \\
\hline Grade II & 25 & $(50 \%)$ & 7 & $(28 \%)$ & 18 & $(72 \%)$ & \\
\hline Grade III & 10 & $(20 \%)$ & 0 & $(0 \%)$ & 10 & $(100 \%)$ & \\
\hline$\underline{\text { Size }}$ & & & & & & & \\
\hline
\end{tabular}




\begin{tabular}{|c|c|c|c|c|c|c|c|}
\hline$<4 \mathrm{~cm}$ & 20 & $(40 \%)$ & 17 & $(85 \%)$ & 3 & $(15 \%)$ & \multirow[t]{2}{*}{$0.007+$} \\
\hline$>4 \mathrm{~cm}$ & 30 & $(60 \%)$ & 5 & $(17 \%)$ & 25 & $(83 \%)$ & \\
\hline \multicolumn{8}{|l|}{ Myometrial invasion } \\
\hline$<50 \%$ & 18 & $(36 \%)$ & 18 & $(100 \%)$ & 0 & $(0 \%)$ & \multirow[t]{2}{*}{$0.002+$} \\
\hline$>50 \%$ & 32 & $(64 \%)$ & 4 & $(12.5 \%)$ & 28 & $(87.5 \%)$ & \\
\hline \multicolumn{8}{|l|}{$\underline{\text { LVSI }}$} \\
\hline Absent & 32 & $(64 \%)$ & 20 & $(62.5 \%)$ & 12 & $(502 \%)$ & \multirow[t]{2}{*}{$0.006 \div$} \\
\hline Present & 18 & $(36 \%)$ & 2 & $(11.1 \%)$ & 16 & $(88.9 \%)$ & \\
\hline \multicolumn{8}{|l|}{ Cervical stromal invasion } \\
\hline Absent & 20 & $(40 \%)$ & 18 & $(60 \%)$ & 2 & $(40 \%)$ & \multirow[t]{2}{*}{$0.003 \$$} \\
\hline Present & 30 & $(60 \%)$ & 4 & $(20 \%)$ & 26 & $(80 \%)$ & \\
\hline \multicolumn{8}{|l|}{$\underline{\text { Parametrial extension }}$} \\
\hline Absent & 40 & $(80 \%)$ & 18 & $(45 \%)$ & 22 & $(55 \%)$ & \multirow[t]{2}{*}{$0.008+$} \\
\hline Present & 10 & $(20 \%)$ & 4 & $(40 \%)$ & 6 & $(60 \%)$ & \\
\hline \multicolumn{8}{|l|}{$\underline{\text { Serosal invasion }}$} \\
\hline Absent & 40 & $(80 \%)$ & 18 & $(45 \%)$ & 22 & $(55 \%)$ & \multirow[t]{2}{*}{$0.04 t$} \\
\hline Present & 10 & $(20 \%)$ & 4 & $(40 \%)$ & 6 & $(60 \%)$ & \\
\hline \multicolumn{8}{|l|}{ Adnexal invasion } \\
\hline Absent & 35 & $(70 \%)$ & 20 & $(57 \%)$ & 15 & $(43 \%)$ & \multirow[t]{2}{*}{$0.002 \ddagger$} \\
\hline Present & 15 & $(30 \%)$ & 2 & $(13 \%)$ & 13 & $(87 \%)$ & \\
\hline \multicolumn{8}{|l|}{ Peritoneal cytology } \\
\hline Negative & 25 & $(50 \%)$ & 12 & $(48 \%)$ & 13 & $(52 \%)$ & \multirow[t]{2}{*}{$0.06 t$} \\
\hline Positive & 25 & $(50 \%)$ & 10 & $(40 \%)$ & 15 & $(60 \%)$ & \\
\hline \multicolumn{8}{|l|}{$\underline{\mathrm{LN}}$} \\
\hline Node negative & 30 & $(60 \%)$ & 20 & $(66.7 \%)$ & 10 & $(33.3 \%)$ & \multirow[t]{2}{*}{$0.001+$} \\
\hline Node positive & 20 & $(40 \%)$ & 2 & $(10 \%)$ & 18 & $(90 \%)$ & \\
\hline \multicolumn{8}{|l|}{$\underline{\mathrm{M}}$} \\
\hline M0 (non-metastatic) & 40 & $(80 \%)$ & 22 & $(55 \%)$ & 18 & $(45 \%)$ & \multirow[t]{2}{*}{$0.001+$} \\
\hline M1 (metastatic) & 10 & $(20 \%)$ & 0 & $(0 \%)$ & 10 & $(100 \%)$ & \\
\hline \multicolumn{8}{|l|}{ FIGO Stage } \\
\hline Stage I & 15 & $(30 \%)$ & 13 & $(86.7 \%)$ & 2 & $(13.3 \%)$ & \multirow[t]{4}{*}{$<0.001 \S$} \\
\hline Stage II & 10 & $(20 \%)$ & 6 & $(60 \%)$ & 4 & $(40 \%)$ & \\
\hline Stage III & 15 & $(30 \%)$ & 3 & $(20 \%)$ & 12 & $(80 \%)$ & \\
\hline Stage IV & 10 & $(20 \%)$ & 0 & $(0 \%)$ & 10 & $(100 \%)$ & \\
\hline \multicolumn{8}{|l|}{ Piwil1 } \\
\hline Low & 18 & $(43.3 \%)$ & 9 & $(50 \%)$ & 17 & $(94 \%)$ & \multirow[t]{2}{*}{$<0.001+$} \\
\hline High & 32 & $(56.7 \%)$ & 22 & $(68.7 \%)$ & 15 & $(44.8 \%)$ & \\
\hline
\end{tabular}

Categorical variables were expressed as number (percentage), continuous variables were expressed as mean \pm SD \& median (range); *Independent samples Student's test; \& Chi-square test; $\S$ Chi-square test for trend; $\mathrm{p}<0.05$ is significant.

Table 3:- correlation between clinicopathological features and Piwill expression in our patients.

\begin{tabular}{|c|c|c|c|c|c|c|c|}
\hline \multirow[t]{3}{*}{ Characteristics } & \multirow{2}{*}{\multicolumn{2}{|c|}{$\begin{array}{c}\text { All } \\
(\mathrm{N}=50)\end{array}$}} & \multicolumn{4}{|c|}{ Piwill } & \multirow[t]{3}{*}{ p-value } \\
\hline & & & \multicolumn{2}{|c|}{$\begin{array}{c}\text { Low } \\
(\mathrm{N}=18)\end{array}$} & \multicolumn{2}{|c|}{$\begin{array}{c}\text { High } \\
(\mathrm{N}=32)\end{array}$} & \\
\hline & No. & $(\%)$ & No. & $(\%)$ & No. & $(\%)$ & \\
\hline \multicolumn{8}{|l|}{ Age (years) } \\
\hline Mean $\pm \mathrm{SD}$ & 50.10 & \pm 5.82 & 45.48 & \pm 5.68 & 50.35 & \pm 8.18 & \multirow[t]{2}{*}{$0.03 *$} \\
\hline Median (Range) & 50 & $(35-65)$ & 45 & $(30-60)$ & 50 & $(30-65)$ & \\
\hline$\leq 55$ years & 30 & $(60 \%)$ & 15 & $(50 \%)$ & 15 & $(50 \%)$ & \multirow[t]{2}{*}{$0.02+$} \\
\hline$>55$ years & 20 & $(40 \%)$ & 3 & $(15 \%)$ & 17 & $(85 \%)$ & \\
\hline \multicolumn{8}{|l|}{ Grade } \\
\hline Grade I & 15 & $(30 \%)$ & 10 & $(67 \%)$ & 5 & $(33 \%)$ & $0.002 \S$ \\
\hline
\end{tabular}




\begin{tabular}{|c|c|c|c|c|c|c|c|}
\hline Grade II & 25 & $(50 \%)$ & 8 & $(32 \%)$ & 17 & $(68 \%)$ & \\
\hline Grade III & 10 & $(20 \%)$ & 0 & $(0 \%)$ & 10 & $(100 \%)$ & \\
\hline \multicolumn{8}{|l|}{ Size } \\
\hline$<\overline{4 \mathrm{~cm}}$ & 20 & $(40 \%)$ & 15 & $(75 \%)$ & 5 & $(25 \%)$ & \multirow[t]{2}{*}{$0.009 \$$} \\
\hline$>4 \mathrm{~cm}$ & 30 & $(60 \%)$ & 3 & $(10 \%)$ & 27 & $(90 \%)$ & \\
\hline \multicolumn{8}{|l|}{ Myometrial invasion } \\
\hline < <50\% & 18 & $(36 \%)$ & 14 & $(77.8 \%)$ & 4 & $(22.2 \%)$ & \multirow[t]{2}{*}{$0.008 \$$} \\
\hline$>50 \%$ & 32 & $(64 \%)$ & 4 & $(12.5 \%)$ & 28 & $(87.5 \%)$ & \\
\hline \multicolumn{8}{|l|}{ LVSI } \\
\hline Absent & 32 & $(64 \%)$ & 16 & $(50 \%)$ & 16 & $(50.2 \%)$ & \multirow[t]{2}{*}{$0.006 t$} \\
\hline Present & 18 & $(36 \%)$ & 2 & $(11.1 \%)$ & 16 & $(88.9 \%)$ & \\
\hline \multicolumn{8}{|l|}{ Cervical stromal invasion } \\
\hline Absent & 20 & $(40 \%)$ & 12 & $(60 \%)$ & 8 & $(40 \%)$ & \multirow[t]{2}{*}{$0.003 \$$} \\
\hline Present & 30 & $(60 \%)$ & 6 & $(20 \%)$ & 24 & $(80 \%)$ & \\
\hline \multicolumn{8}{|l|}{ Parametrial extension } \\
\hline Absent & 40 & $(80 \%)$ & 16 & $(50 \%)$ & 24 & $(50 \%)$ & \multirow[t]{2}{*}{$0.005 \$$} \\
\hline Present & 10 & $(20 \%)$ & 2 & $(11.1 \%)$ & 8 & $(88.9 \%)$ & \\
\hline \multicolumn{8}{|l|}{ Serosal invasion } \\
\hline Absent & 40 & $(80 \%)$ & 15 & $(37.5 \%)$ & 25 & $(62.5 \%)$ & \multirow[t]{2}{*}{$0.005 t$} \\
\hline Present & 10 & $(20 \%)$ & 3 & $(30 \%)$ & 7 & $(70 \%)$ & \\
\hline \multicolumn{8}{|l|}{ Adnexal invasion } \\
\hline Absent & 35 & $(70 \%)$ & 15 & $(42.8 \%)$ & 20 & $(57.2 \%)$ & \multirow[t]{2}{*}{$0.02 \ddagger$} \\
\hline Present & 15 & $(30 \%)$ & 3 & $(20 \%)$ & 12 & $(80 \%)$ & \\
\hline \multicolumn{8}{|l|}{ Peritoneal cytology } \\
\hline Negative & 25 & $(50 \%)$ & 10 & $(40 \%)$ & 15 & $(60 \%)$ & \multirow[t]{2}{*}{$0.001 \%$} \\
\hline Positive & 25 & $(50 \%)$ & 8 & $(32 \%)$ & 17 & $(68 \%)$ & \\
\hline \multicolumn{8}{|l|}{$\underline{\mathrm{LN}}$} \\
\hline Node negative & 30 & $(60 \%)$ & 17 & $(56.7 \%)$ & 13 & $(43.3 \%)$ & \multirow[t]{2}{*}{$0.001 \%$} \\
\hline Node positive & 20 & $(40 \%)$ & 1 & $(5 \%)$ & 19 & $(95 \%)$ & \\
\hline \multicolumn{8}{|l|}{$\underline{\mathrm{M}}$} \\
\hline M0 (non-metastatic) & 40 & $(80 \%)$ & 18 & $(45 \%)$ & 22 & $(55 \%)$ & \multirow[t]{2}{*}{$0.009 \ddagger$} \\
\hline M1 (metastatic) & 10 & $(20 \%)$ & 0 & $(0 \%)$ & 10 & $(100 \%)$ & \\
\hline \multicolumn{8}{|l|}{ FIGO Stage } \\
\hline Stage I & 15 & $(30 \%)$ & 10 & $(66.7 \%)$ & 5 & $(34.3 \%)$ & \multirow{4}{*}{$<0.001 \S$} \\
\hline Stage II & 10 & $(20 \%)$ & 5 & $(50 \%)$ & 5 & $(50 \%)$ & \\
\hline Stage III & 15 & $(30 \%)$ & 3 & $(20 \%)$ & 12 & $(80 \%)$ & \\
\hline Stage IV & 10 & $(20 \%)$ & 0 & $(0 \%)$ & 10 & $(100 \%)$ & \\
\hline \multicolumn{8}{|l|}{$\underline{\mathrm{SOX} 2}$} \\
\hline Low & 22 & $(43.3 \%)$ & 17 & $(77 \%)$ & 15 & $(68 \%)$ & \multirow{2}{*}{$<0.001 \ddagger$} \\
\hline High & 28 & $(56.7 \%)$ & 22 & $(78.6 \%)$ & 9 & $(32 \%)$ & \\
\hline
\end{tabular}

Categorical variables were expressed as number (percentage), continuous variables were expressed as mean \pm SD \& median (range); *Independent samples Student's test; \$Chi-square test; $§$ Chi-square test for trend; $\mathrm{p}<0.05$ is significant.

\section{Discussion:-}

SOX-2 is previously described as a transcription factor that had many roles in cancer metastasis, and its aberrant expression has been detected in cancers of many organs [21]. SOX-2 overexpression has found to be related to bad clincopathological criteria and poorer outcomes in many cancers [22-24]. However, little is known about SOX-2 expression and their relationship to clinicopathological features in EMC.

In our study, we found that high expression of SOX2 was positively correlated with bad clinicopathological parameters of EMC patients like advanced age of the patient, increased cancer size, higher grade, advanced stage of the tumor, presence of L.N and distant metastases, presence of myometrial, lymphovascular, parametrial, serosal, 
cervical stromal and adnexal invasions. These results are consistent with results of Pityński et al., who found that Sox-2 overexpression was related to higher grade of endometrial carcinoma but they have not described relations between such expression and cancer stage or metastases because they made their research only on early stage endometrial carcinoma [19], but here in our study we have made correlations with the stage and metastases as we have included all stages, similar to our results the results of Yang et al., that demonstrated that SOX-2 overexpression in patients having small cell lung cancer with were associated with advanced cancer stages and increased liability to lymph node metastases [25]. Neumann et al., proved that high SOX2 expression was positively correlated with higher incidence of nodal, liver and distant metastasis [26]. Similar to ours Ruan et al., , determined that SOX-2 overexpression in cancer bladder was positively associated with increased tumor size and grade[22]. Also similar to our results regarding the association of SOX-2 overexpression and higher grade of EMC many previous studies proved the same association with higher grade in cancer breast, cervix, colon and lung [19\& 23]. All these results proved the essential role of SOX-2 in the carcinogenic process that controls cancer cell proliferation potential.

We found here that Sox 2 overexpression in EMC was positively correlated with advanced age of the patient that was different from results of Wilbertz $\mathbf{T}$, et al., in squamous cell lung cancer that showed increased SOX2 expression correlating with younger patient age, but he did not explain his results [27].

Yang et al., found that Sox2 expression had a predictive role in earlier stage gastric cancer (Stages I\& II), but not advanced stages (Stages III\& IV) [28] that supported that Sox-2 expression is correlated with a poor prognosis at earlier cancer stages but here we proved its prognostic roles in advanced and early stages of EMC.

Sox-2 is a transcription factor that had many roles in cancer biology [29\& 30]. It may have an oncogenic role or tumor suppressor, [Otsubo et al., had clarified its tumor suppressor role by inhibition of cell growth through cyclin $\mathrm{D} 1$ and phosphorylated $\mathrm{Rb}$ regulation [31]. It could also directly activate PTEN [32]. In addition, Sox2 inhibits cancer cells spread by up regulating the expression of p21 [33]. Sox 2 oncogenic roles was detected in gastric cancer and its blocking could reduce gastric cancer cell invasion and metastases [34], the oncogenic role could be explained by that SOX-2 is a stem cell transcription factor which its aberrant expression impairs the cancer stem cell like phenotype [35]. Due to the importance of CSCs hypothesis an cancer management and the development of specific therapies required detailed identification of their specific markers and due to some conflicting results about SOX-2 expression in cancer we assesses the expression of another marker of CSCs which is Piwil-1. Previous studies showed that Piwi 1 protein was overexpressed in many solid cancers [36], and such expression was positively correlated with advanced stage, higher grade, presence of lymph node\& distant metastasis [37\& 38]. That was explained by that Piwill had an essential role in increasing malignant potential in cancer cells increasing their proliferation [39] and invasion [40], , also piwill was found to be essential for stem cell self-renewal, division, so it may regulate cancer stem cell development [41]. However, researchers that had focused on the roles of Piwil1 in EMC biology are few and gave conflicting results. In this study, we focused on the role of Piwill aberrant expression in EMC, and we found that high expression of Piwill expression in endometrial carcinoma was positively correlated with advanced age of the patient, increased cancer size, higher grade, advanced stage of the tumor, presence of L.N and distant metastases, presence of myometrial, lymphovascular, parametrial, serosal, cervical stromal and adnexal invasions. These results are consistent with results of Chen et al., 2015 that proved the same results in endometrial carcinoma and Wang et al., 2012\& He et al. that found similar results in gastric\& esophageal carcinoma [37 \&42]. Chen et al., explained these results by proving that Piwill is one of the molecular biomarkers that are necessary for increasing cancer cell's liability for self-renewal in endometrial carcinoma, they have stated that Piwill overexpression increased levels of CSCs markers CD44 and ALDH1 while its down regulation decreased levels of expression of these markers, so they proved that Piwill may regulate endometrial cancer stemness [20]. Another explanation of the role of Piwill overexpression in cancer is that it was involved in EMT. As they found that that Piwill decreased epithelial marker such as E-cadherin and increased mesenchymal markers such as Vimentin and N-cadherin in endometrial carcinoma cells. It was found that snail 1 played an essential role in EMT [43], and its down regulation reversed EMT and inhibited cancer motility, invasion and stem cell-like criteria of cancer cells [45]. Chen et al., showed that Piwill could down regulate the snail 1 transcription, proving that Piwill may be needed for Snail stimulated EMT [20]. Previous reports proved that Piwill overexpression increased cancer-related fatalities [14\& 15], and is a poor prognostic parameter for many cancers e.g. gastric, esophageal and hepatocellular carcinomas [37, 40\& 42] that was similar to our results. Also, we found a positive correlation between Piwill over-expression, lymphovascular, myometrial invasions, lymph node metastasis and advanced disease stage, all of which are considered high risk factors in EMC which was similar to results of 
Chen et al., [20]. Our results are not enough to identify Piwill as a clear prognostic factor for EMC as our study lake survival and followup analysis but our expression data together with our results suggest that Piwill could be studied as a novel target for anti-cancer therapy. And, more studies with follow up and survival data are needed to clarify the detailed roles of Piwill in EMC progression and carcinogenesis. We found a significantly positive relation between Sox-2 and Piwil-1 expression in EMC and overexpression of both of them were correlated with poor clinicopathological parameters of EMC, so they could be used together as prognostic markers and therapeutic targets

\section{Summary:-}

we found that Sox-2\& Piwil1 co expressions could induce stemness and stimulate EMT in endometroid carcinoma, so they might be promising targets for developing novel treatment strategies for endometrial carcinoma

The main limits of our study were lack of recurrence and survival data. So we recommend doing future study on large number of cases which would validate our results.

\section{Conclusion:-}

Sox-2\& Piwill co expressions are markers of poor prognosis in endometrial carcinoma.

\section{Refrences:-}

1. Brennan, D.J.; Hackethal, A; Metcalf, A.M.; Coward, J; Ferguson, K; Oehler, M.K.; et al., "SerumHE4 as a prognostic marker in endometrial cancer-apopulation based study," Gynecologic Oncology, vol. 132, no. 1, pp. 159-165, 2014.

2. Jemal A, Bray F, Center MM, Ferlay J, Ward E, Forman D.., Global cancer statistics. CA Cancer J Clin 2011; 61: 69-90.

3. Zhou X, Zhou YP, Huang GR, Gong BL, Yang B, Zhang DX, et al., Expression of the stem cell marker Nanog in human endometrial adenocarcinoma. Int J Gynecol Pathol 2011; 30: 262-270.

4. Hubbard SA, Friel AM, Kumar B, Zhang L, Rueda BR, Gargett CE et al., Evidence for cancer stem cells in human endometrial carcinoma. Cancer Res. 2009;69(21):8241-8.

5. Mirantes C, Espinosa I, Ferrer I, Dolcet X, Prat J, Matias-Guiu X et al., Epithelial-tomesenchymal transition and stem cells in endometrial cancer. Hum Pathol. 2013;44(10):1973-81.

6. Skidan I, Steiniger SC. In vivo models for cancer stem cell research: a practical guide for frequently used animal models and available biomarkers. J Physiol Pharmacol 2014; 65: 157-169.

7. Niwa H. How is pluripotency determined and maintained? Development 2007; 134: 635-646.

8. Sarkar A, Hochedlinger K. The sox family of transcription factors: versatile regulators of stem and progenitor cell fate. Cell Stem Cell 2013; 12: 15-30.

9. Bessede E, Staedel C, Acuna Amador LA, Nguyen PH, Chambonnier L, Hatakeyama M et al., Helicobacter pylori generates cells with cancer stem cell properties via epithelial-mesenchymal transition-like changes. Oncogene 2013: e-pub ahead of print 7 October 2013; doi: 2010.1038/onc.2013.2380.

10. Cox DN, Chao A, Baker J, Chang L, Qiao D, Lin H., A novel class of evolutionarily conserved genes defined by piwi are essential for stem cell self-renewal. Genes Dev. 1998; 12(23):3715-27.

11. Cox DN, Chao A, Lin H. Piwi encodes a nucleoplasmic factor whose activity modulates the number and division rate of germline stem cells. Development. 2000; 127:503-14.

12. Pal-Bhadra M, Leibovitch BA, Gandhi SG, Chikka MR, Bhadra U, Birchler JA,et al., Heterochromatic silencing and HP1 localization in Drosophila are dependent on the RNAi machinery. Science 2004; 303: 669672.

13. Grivna ST, Pyhtila B, Lin H. MIWI associates with translational machinery and PIWI-interacting RNAs (piRNAs) in regulating spermatogenesis. Proc Natl Acad Sci USA 2006; 103: 13415- 13420.

14. Taubert H, Greither T, Kaushal D et al. Expression of the stem cell self-renewal gene Hiwi and risk of tumour-related death in patients with soft-tissue sarcoma. Oncogene. 2007;26(7):1098-100.

15. Grochola LF, Greither T, Taubert H, P Möller, U Knippschild, A Udelnow, et al. The stem cell-associated Hiwi gene in human adenocarcinoma of the pancreas: expression and risk of tumour-related death. Br $\mathrm{J}$ Cancer. 2008;99(7):1083-8.

16. Creasman W. Revised FIGO staging for carcinoma of the endometrium. Int J Gynaecol Obstet. 2009;105(2):109. 
17. Lewin SN, Herzog TJ, Barrena Medel NI, Deutsch I, Burke WM, Sun X et al. Comparative performance of the 2009 international federation of gynecology and obstetrics' staging system for uterine corpus cancer. Obstet Gynecol. 2010; 116(5):1141-9.

18. Hsu SM, Raine L, Fanger H. Use of avidin-biotin-peroxidase complex (ABC) in immunoperoxidase techniques: a comparison between $\mathrm{ABC}$ and unlabeled antibody (PAP) procedures. J HistochemCytochem. $1981 ; 29: 577-580$.

19. Pityński K, Banas T, Pietrus M, Milian-Ciesielska K, Ludwin A, Okon K. SOX-2, but not Oct4, is highly expressed in early-stage endometrial adenocarcinoma and is related to tumour grading Int $\mathrm{J}$ Clin Exp Pathol 2015;8(7):8189-8198 www.ijcep.com /ISSN:1936-2625/IJCEP0009366

20. Chen Z, Che Q, He X, Wang F, Wang H, Zhu M et al., Stem cell protein Piwill endowed endometrial cancer cells with stem-like properties via inducing epithelial-mesenchymal transition. BMC Cancer (2015) 15:811 DOI 10.1186/s12885-015-1794-8.

21. Lin CW, Liao MY, Lin WW, Wang YP, Lu TY, Wu HC. Epithelial cell adhesion molecule regulates tumor initiation and tumorigenesis via activating reprogramming factors and epithelial-mesenchymal transition gene expression in colon cancer. J Biol Chem 2012; 287: 39449-39459.

22. Ruan J, Wei B, Xu Z, , Yang S, Zhou Y, Yu M et al., Predictive value of Sox2 expression in transurethral resection specimens in patients with T1 bladder cancer. Med Oncol 2013; 30: 445.

23. Ji J, Wei X, Wang Y. Embryonic stem cell markers Sox-2 and OCT4 expression and their correlation with WNT signal pathway in cervical squamous cell carcinoma. Int J Clin Exp Pathol 2014; 7: 2470-2476.

24. Wang Q, He W, Lu C, Wang Z, Wang J, Giercksky KE et al., Oct3/4 and Sox 2 are significantly associated with an unfavorable clinical outcome in human oesophageal squamous cell carcinoma. Anticancer Res 2009; 29: 1233-1241.

25. Yang F, Gao Y, Geng J, Qu D, Han Q, Qi J et al., Elevated expression of SOX2 and FGFR1 in correlation with poor prognosis in patients with small cell lung cancer. Int J Clin Exp Pathol 2013; 6: 2846-2854.

26. Neumann J, Bahr F, Horst D, Krieg L, Enge J, Mejías-Luque R et al. SOX2 expression correlates with lymph-node metastases and distant spread in right-sided colon cancer. BMC Cancer. 2011; 11: 518.

27. Wilbertz T, Wagner P, Petersen K, Stiedl AC, Scheble VJ, Maier S et al. SOX2 gene amplification and protein overexpression are associated with better outcome in squamous cell lung cancer. Mod Pathol. 2011; 24: 944- 953.

28. Yang L, Xu J, Kang Q, Li AQ, Jin P, Wang $\mathbf{X}$ et al., Predictive Value of Stemness Factor Sox2 in Gastric Cancer Is Associated with Tumor Location and Stage PLOS ONE | DOI:10.1371/journal.pone.0169124, 2017

29. Weina K,Utikal J. SOX2 and cancer: current research and its implications in the clinic. Clin Transl Med. 2014; 3:19. Epub 2014/08/13. doi: 10.1186/2001-1326-3-19 PMID: 25114775

30. Carrasco-Garcia E, Santos JC, Garcia I, Brianti M, Garcia-Puga M, Pedrazzoli J Jr et al. Paradoxical role

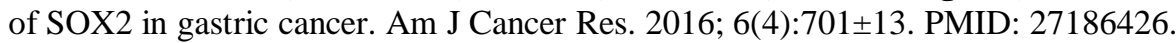

31. . Otsubo T, Akiyama Y, Yanagihara K, Yuasa Y. SOX2 is frequently downregulated in gastric cancers and inhibits cell growth through cell-cycle arrest and apoptosis. Br J Cancer. 2008; 98(4):824 \pm 831 . doi: 10.1038/sj.bjc.6604193 PMID: 18268498

32. Wang S, Tie J, Wang R, Hu F, Gao L, Wang Wet al. SOX2, a predictor of survival in gastric cancer, inhibits cell proliferation and metastasis by regulating PTEN. Cancer Lett. 2015; 358(2):210 \pm 219 . doi: 10.1016/j.canlet.2014.12.045 PMID: 25543086

33. Chen Y, Huang Y, Zhu L, , Chen M1, Huang Y1, Zhang J et al. SOX2 inhibits metastasis in gastric cancer. J Cancer Res Clin Oncol. 2016; 142(6):1221 \pm 1230 . doi: 10.1007/s00432-016-2125-4 PMID: 26960758

34. Hutz K, Mejias-Luque R, Farsakova K, Chen M1, Huang Y1, Zhang J et al. The stem cell factor SOX2 regulates the tumorigenic potential in human gastric cancer cells. Carcinogenesis. 2014; 35(4):942 \pm 950 . doi: 10.1093/carcin/bgt410 PMID: 24325912

35. Shen JX, Liu J, Li GW, Huang YT, Wu HT. Mining distinct aldehyde dehydrogenase 1 (ALDH1) isoenzymes in gastric cancer. Oncotarget. 2016. Epub 2016/03/26.

36. Suzuki R, Honda S, Kirino Y. PIWI Expression and Function in Cancer. Front Genet. 2012; 3:204.

37. Wang Y, Liu Y, Shen $\mathbf{X}$, Zhang $\mathbf{X}$, Chen $\mathbf{X}$, Yang $\mathbf{C}$ et al. The PIWI protein acts as a predictive marker for human gastric cancer. Int J Clin Exp Pathol. 2012; 5(4):315-25.

38. Li L, Yu C, Gao H, Li Y. Argonaute proteins: potential biomarkers for human colon cancer. BMC Cancer. 2010;10:38.

39. Liang D, Fang Z, Dong M, Liang C, Xing C, Zhao J et al. Effect of RNA interference-related HiWi gene expression on the proliferation and apoptosis of lung cancer stem cells. Oncol Lett. 2012;4(1):146-50. 
40. Zhao YM, Zhou JM, Wang LR, He HW, Wang XL, Tao ZH et al. HIWI is associated with prognosis in patients with hepatocellular carcinoma after curative resection. Cancer. 2012;118(10):2708-17.

41. Sharma AK. Human CD34+ stem cells express the hiwi gene, a human homologue of the Drosophila gene piwi. Blood. 2001;97(2):426-34.

42. He W, Wang Z, Wang Q, Fan Q, Shou C, Wang J et al. Expression of HIWI in human esophageal squamous cell carcinoma is significantly associated with poorer prognosis. BMC Cancer. 2009; 9:426.

43. Cano A, Pérez-Moreno MA, Rodrigo I, Locascio A, Blanco MJ, del Barrioet MG al. The transcription factor Snail controls epithelial-mesenchymal transitions by repressing E-cadherin expression. Nat Cell Biol. 2000; 12:76-83.

44. Ohta K, Hoshino H, Wang J, Ono S, Iida Y, Hata K et al. MicroRNA-93 activates c-Met/PI3K/Akt pathway activity in hepatocellular carcinoma by directly inhibiting PTEN and CDKN1A. Oncotarget. 2015;6(5):321124. 